\title{
Seismic Vulnerability Assessment using Numerical Simulation for a Residential Buildings - A Case study
}

Jennifer Mehjebin

Vellore Institute of Technology: VIT University

Santhi A.S

Vellore Institute of Technology: VIT University

Ganapathy Pattukandan Ganapathy ( $\nabla$ seismogans@yahoo.com )

VIT University https://orcid.org/0000-0002-3356-6508

\section{Research}

Keywords: Rapid Visual Screening, Seismic vulnerability, Shear wall, ETABS

Posted Date: September 2nd, 2020

DOI: https://doi.org/10.21203/rs.3.rs-70268/v1

License: (c) (i) This work is licensed under a Creative Commons Attribution 4.0 International License.

Read Full License 


\section{Abstract}

Seismic vulnerability assessment of an existing building is of high importance for ensuring the safety of the structure and the occupants. An earthquake may not be predictable but seismic performance of a structure can be well- predicted in advance which aids in deciding the correct retrofit technique for a building ensuring the safety of the occupants. A RC building situated in the seismic zone III region of Vellore, Tamil Nadu has been taken into consideration for analysing its seismic vulnerability. The region is yet to catch engineering attention for evaluation of seismic performance of such buildings. With the help of the nearest fault line data, the PGA value was calculated and the value suggested moderate potential damage. The RVS score of the building was categorised in the high probability of Grade Damage 3 i.e. structural damage in moderate range and non-structural damage in heavy range. A detailed numerical analysis was carried out in ETABS using equivalent static force method to simulate the earthquake forces in the structure. Although a dynamic method of analysis considers higher magnitude of earthquake forces based on a more realistic earthquake excitation, equivalent static force analysis is sufficient for a preliminary analysis of the building. The building having a soft storey in the ground floor showed variations in its behaviour on application of earthquake forces in four different case scenarios of shear wall application. The maximum storey drifts were then compared for the building in cases of existing soft storey and with the application of shear wall in the ground floor, staircase walls and with a combination of shear wall in both the locations. The results showed that shear wall in the staircase proved to be the most economical retrofit solution for the building.

\subsection{Introduction}

Vulnerability is the amount of damage induced by a hazard and expressed as the fraction of the value of the designed item under construction (Dowrick 2003). India has witnessed devastating earthquakes in the past affecting both human life and structures and this calls for more attention to the field of seismic vulnerability assessment and risk mitigation. Calvi et.al. (2006) studied the seismic vulnerability assessment methodologies over the past three decades and concluded that there should be employment of atleast two different approaches to verify the obtained results (Calvi et al. 2006). Building vulnerability assessment proves to be a reliable tool for evaluating damage and loss scenarios for risk mitigation and management (Vicente et al. 2008). A deterministic approach proves to be beneficial for such risk assessment and mitigation studies (Elayaraja et al. 2015). The concerned study focuses on finding the seismic vulnerability using both empirical and analytical methods - a deterministic approach for an existing nine-storied RC building located in Vellore, Tamil Nadu, a zone III (BIS 2002) region of the Indian subcontinent which is prone to moderate to strong earthquakes with a maximum expected magnitude of 6.9 (Fig. 1). Ganapathy (2010) found in an evaluation of seismic hazard analysis in Tamil Nadu, distinguishing the fault lines of the state and evaluating the peak ground accelerations, that the Northern part of Tamil Nadu experienced frequent earthquake activity. It showed a higher value of seismic hazard compared to other parts and stated that the Northern and East-Southeastern part of the state required extra attention for future research (G P Ganapathy 2010). A few of the recent earthquakes recorded in 
Vellore, situated in the Northern part of the state, were on 13/08/2010 of magnitude 3.1 in Pernambet, 55 kilometres from Vellore and another one on 24/03/2018 resulting in cracks in buildings. The past seismic activities in the region are depicted in the regional map in Fig. 2.

The structure taken in the present study has a ground coverage area of 1431.936 metre $^{2}$ and a total elevation of 31.12 metres with more than 200 residents making it an important building as per the rules of Rapid Visual Screening Manual (more than 100 occupants). A vulnerability assessment appeared to be necessary on such a residential building to ensure the safety of the occupants. The objective of the study was to analyse the existing structure and propose measures to minimize the risk threats posed to the building and its residents. The building in the study has a soft storey in the ground floor causing reduction of stiffness in that portion of the building. Dya and Oretaa (2015) found that buildings with vertical irregularity tend to be more susceptible to earthquake damage due to the localisation of seismic forces (Dya and Oretaa 2015). Lu et. al. (2008) and Tang et. al. (2011) stated that conducting physical tests to study the collapse mechanism is time-consuming and difficult and hence, numerical simulation serves as a major method to assess such failure mechanisms in lesser time ( Lu et al. 2008 ; Tang et al. 2011).

The Rapid Visual Screening (RVS) procedure is an empirical approach to score buildings based on its potential risk threat which requires the assessor to visually identify the behaviour of the structural attributes of the building in the occurrence of an earthquake. RVS report for SAARC countries (2011) suggested that further detailed analysis might be needed to check the need for retrofitting based on the seismic adequacy of vulnerable buildings (RVS procedure in SAARC Countries 2011). Generally, a low RVS score $<2$ demands a detailed analysis to simulate earthquake scenario (Ghafar et. al 2015; Kassem et al. 2020).

In the present study rapid visual screening (RVS) score was found to be $1.8(<2)$ (Table 4) and hence, a more detailed numerical analysis had been carried out in ETABS using equivalent lateral force procedure. Alghuff et al. (2019) carried out a comparative study for static and dynamic analysis (response spectrum analysis) for regular RC buildings and found displacements in dynamic analysis to be $15 \%$ lesser than the corresponding values obtained using equivalent static analysis and recommended static approach for low rise and regular buildings (Alghuff et al. 2019). Keyhani and Shafiee (2016) analysed various retrofit methods and found that steel bracing and shear wall were the most effective in reducing lateral displacement (Keyhani and Shafiee 2016). Kyriakides et al. (2015) carried out an experiment to find that $\mathrm{RC}$ infill frame increased the capacity of the strengthened frame by 5 times compared to a bare frame and stated that a brick infill wall is not sufficient to provide the needed stiffness and strenth to a building for severe earthquake (Kyriakides et al. 2015). Ganapathy and Manoharan (2020) highlighted the need for earthquake planning in urbanised areas and the importance of designing a realistic image of an anticipated earthquake in order to minimise risks and damages (Ganapathy and Manoharan 2020).

\subsection{Study Area}


Vellore district is situated between $12^{\circ} 37^{\prime \prime} 46^{\prime \prime} \mathrm{N}$ to $13^{\circ} 10^{\prime} 27^{\prime \prime} \mathrm{N}$ and $78^{\circ} 34^{\prime} 50^{\prime \prime} \mathrm{E}$ to $79^{\circ} 21^{\prime} 1.636 " \mathrm{E}$ in Tamil Nadu, India with a geographical area of 2030.11 sq. k.m. It is bounded on the North by Chittoor district of Andhra Pradesh, on the South by Thiruvannamalai district, on the West by Tirupattur district, and on the East by Ranipet district. Vellore being the head-quarter of the Vellore district is well connected by train routes and highways to major towns of the neighbouring states. Physiographically the North-Western parts of the district are endowed with hilly terrain and the eastern side of the district is mostly covered by rocky plains. The district has a population of $16,14,242$ as per the 2011 census.

\subsection{Materials And Methods}

In the first stage, the site located in Katpadi Village of Vellore District was selected and the required site data were acquired from the concern land authorities for the preliminary survey. The peak ground acceleration was calculated using the nearest fault line data (Table 1) and a final hazard score was obtained from the rapid visual screening (RVS) procedure. The RVS was selected for the knowledge of the basic hazard score and the probable damage that could occur in different intensities of earthquake. In the second phase, a detailed seismic vulnerability assessment was carried out by designing the structure using ETABS. Numerical simulation using the existing plan, elevation and reinforcement detailing aided in analysing the probable failure of the building in the occurrence of an earthquake. The method adopted was equivalent lateral force procedure (IS:1893 2002). The building was then retrofitted using shear walls in critical locations of the building. The difference in the deflection and storey drifts were assessed in the presence of shear walls in the ground floor, staircase and another case with shear wall in both ground floor and the staircase locations to find the most economic retrofit.

\subsection{Results And Discussions}

The Peak Ground Acceleration (PGA) for Tamil Nadu has been calculated using the relation established for the South Indian region (lyengar and Raghu Kanth 2004) :

$\ln y=c 1+c 2(M-6)+c 3(M-6) 2-\ln R-c 4 R+\ln €$

The nearest fault line to the study site is the Changem- Alangayam Gudiyattam lineament with a radial distance of 45 kilometres. The fault lines in the region are shown in Fig. 2. For zone III, PGA value of 0.18-0.34 g implies moderate potential damage and very strong perceived shaking and hence, RVS was carried out. In the RVS procedure, total scores were calculated based on the survey for seismic zones III, IV and V. As per the procedure rules, design seismic force for an important building increases by a factor of 1.5 resulting in an increase of seismic zone intensity by the same factor. Hence, the analysis needs to be carried out using values for one unit higher zone (Arya 2006). The building was studied as per the values of seismic zone IV.

As per the standard values, the final score was 1.8 for Zone IV and $V$ which lies in the high probability of Grade Damage 3 i.e. moderate structural damage and heavy non-structural damage. A detailed study of 
the existing structure was proceeded in the software ETABS. The building was designed using the existing plan dimensions and section properties with appropriate dead load and live load according to the occupancy details. The plan and elevation designed in ETABS is shown in Figs. 3(a) and 3(b) respectively.

For design purpose, values corresponding to Zone IV have been considered for placing the earthquake load combinations on each floor. Shear wall of $0.4 \mathrm{~m}$ thickness was used as a retrofit for this study. Figure 4 depicts the designed original existing structure with soft storey. The various cases of shear wall application are shown in Fig. 5 (a), (b) and (c). These cases were simulated with earthquake forces to obtain the maximum displacement.

Based on the analysis result, it could be interpreted that presence of the shear wall on both the staircase walls and in the soft storey on the ground floor gave a maximum decrement in the drift of the building, which was $66.56 \%$ for $x$-direction and $27.31 \%$ in y-direction and a decrease of overall displacement of $180 \mathrm{~mm}$ from $250 \mathrm{~mm}$. For the case of shear wall only in the ground floor, the overall displacement of the building was observed to have decreased to $200 \mathrm{~mm}$ from $250 \mathrm{~mm}$. Shear wall only on the staircase showed a decrement in the story drift of the building by $64.18 \%$ for $x$-direction and $11.42 \%$ in $y$-direction which might also prove economical for modification (Table 6). Several studies suggested that during the selection of the most optimal strengthening system, another important factor to be considered along with the seismic performance is the cost effectiveness of the system (Necevska-Cvetanovska and Apostolska 2012; Ferreira et al. 2020)

\subsection{Conclusions}

The obtained results show that localisation of seismic forces in the soft storey makes buildings more susceptible to earthquake. In the presence of shear wall in the ground floor and staircase, a significant decrease in the deflection was observed in comparison to the original structure. However, shear wall only in the staircase will prove to be more economical than retrofitting at two locations in the building. Moreover, shear wall in the staircase has shown almost similar decrement percentage in displacement. A shear wall of thickness 0.4 meters in the locations as specified was recommended for the building. The structure may be further simulated for dynamic analysis to check the performance with other retrofitting techniques. Further estimation of human and economic losses could be done to get calculate the overall risk analysis. The entire region is yet to develop awareness about the seismic safety of structures. It is anticipated that the study would be beneficial to prepare a disaster mitigation plan to minimise the risks of potential damage for such buildings and the residents in the area.

\section{Declarations}

\section{Acknowledgements}


The authors are thankful to Vellore Institute of Technology (VIT), Vellore, India for the constant encouragement and support.

\section{Authors' contributions}

The first author carried out the research and the second and third author equally contributed in analysis as well as in the review of the study.

\section{Funding}

NA

\section{Availability of data and materials}

The data available with both first and corresponding Author

\section{Competing interests}

NA

\section{References}

1. Alghuff, Ahmed Yousef, Samir Mohammed Shihada, and Bassam A. Tayeh. 2019. Comparative Study of Static and Response Spectrum Methods for Seismic Analysis of Regular RC Buildings. Journal of Applied Sciences 19: 495-503. https://doi.org/10.3923/jas.2019.495.503.

2. Arya, S. Anand. 2006. Rapid Visual Screening of RCC Buildings. GOI-UNDP Disaster Risk Management Programme, Ministry of Home Affairs, New Delhi. Vol. 13935.

3. BIS (2001), IS 1893: Indian Standard, Criteria for Earthquake Resistant Design of Structures, Bureau of Indian Standards, New Delhi, 2001.

4. Calvi, G M, R Pinho, G Magenes, J J Bommer, L F Restrepo-Vélez, and H Crowley. 2006. 110252013102228Am. ISET Journal of Earthquake Technology, Paper No. 472 43: 75-104.

5. Dowrick, David J. 2003. Earthquake Risk Reduction. First Edit. Chichester, England: John Wiley \& Sons. Ltd. https://doi.org/10.1002/0470869356.

6. Dya, Adrian Fredrick C., and Andres Winston C. Oretaa. 2015. Seismic vulnerability assessment of soft story irregular buildings using pushover analysis. In The 5th International Conference of Euro Asia Civil Engineering Forum (EACEF-5), 125:925-932. ElsevierLtd.

https://doi.org/10.1016/j.proeng.2015.11.103. 
7. Elayaraja, S, S S Chandrasekaran, and G P Ganapathy. 2015. Evaluation of seismic hazard and potential of earthquake-induced landslides of the Nilgiris, India. Natural Hazards 78. Springer Netherlands: 1997-2015. https://doi.org/10.1007/s11069-015-1816-5.

8. Ferreira, Tiago Miguel, Hugo Rodrigues, and Romeu Vicente. 2020. Seismic vulnerability assessment of existing reinforced concrete buildings in urban centers. Sustainability (Switzerland) 12: 1-20. https://doi.org/10.3390/su12051996.

9. Ganapathy, G P. 2010. A deterministic seismic hazard analysis for the major cultural heritage sites of Tamil Nadu, India. International Journal of Geomatics and Geosciences 1: 529-543.

10. Ganapathy, Ganapathy Pattukandan, and Saravana Ganesh Manoharan. 2020. An Interdisciplinary Approach for Disaster Resilience and Sustainability. In An Interdisciplinary Approach for Disaster Resilience and Sustainability, 235-248. Singapore: Springer Nature Singapore Pte Ltd. https://doi.org/10.1007/978-981-32-9527-8.

11. Ghafar, N. Ramly, M. Alel, Azlan Adnan, Edy Tonnizam Mohamad, M.Z.M. Yunus. 2015. A Simplified Method for Preliminary Seismic Vulnerability Assessment of Existing Building in Kundasang, Sabah, Malaysia. Jurnal Teknologi (Sciences \& Engineering) 3: 1-7.

12. IS:1893. 2002. Criteria for Earthquake Resistant Design of Structures - General Provisions and Buildings Part-1. In Bureau of Indian Standards, New Delhi, Part 1:1-39.

13. lyengar, R. N., and S. T.G. Raghu Kanth. 2004. Attenuation of strong ground motion in peninsular India. Seismological Research Letters 75: 530-540. https://doi.org/10.1785/gssrl.75.4.530.

14. Kassem, Moustafa Moufid, Fadzli Mohamed Nazri, and Ehsan Noroozinejad Farsangi. 2020. The seismic vulnerability assessment methodologies: A state-of-the-art review. Ain Shams Engineering Journal. THE AUTHORS. https://doi.org/10.1016/j.asej.2020.04.001.

15. Keyhani, A., and A. Shafiee. 2016. Effectiveness of Seismic Retrofit for Existing Concrete Buildings using Nonlinear Static-Analysis. Indian Journal of Science and Technology 9: 1-8. https://doi.org/10.17485/ijst/2016/v9i2/80060.

16. Kyriakides, Nicholas, Christis Z. Chrysostomou, Panagiotis Kotronis, Elpida Georgiou, and Panayiotis Roussis. 2015. Numerical simulation of the experimental results of a RC frame retrofitted with RC Infill walls. Earthquake and Structures 9: 735-752. https://doi.org/10.12989/eas.2015.9.4.735.

17. Necevska-Cvetanovska, G., and R. Apostolska. 2012. Methodology for Seismic Assessment and Retrofitting of RC Building Structures. In 15th World Conference on Earthquake Engineering (15WCEE). Lisboa.

18. Rapid Structural and Non-structural Assessment of School and Hospital Buildings in SAARC Countries. 2011. SAARC Disaster Management Centre, New Delhi.

19. Tang, Baoxin, Xinzheng Lu, Lieping Ye, and Wei Shi. 2011. Evaluation of collapse resistance of RC frame structures for Chinese schools in seismic design categories B and C. Earthquake Engineering and Engineering Vibration 10: 369-377. https://doi.org/10.1007/s11803-011-0073-1.

20. Vicente, R, S Parodi, S Lagomarsino, H Varum, and J. A. R. Mendes da Silva. 2008. Seismic Vulnerability Assessment Damage Scenarios and Loss Estimation-Case study of the old city centre 
of Coimbra, Portugal. In The 14th World Conference on Earthquake Engineering. Beijing.

21. Xinzheng Lu , Xuchuan Lin, Yuhu Ma , Yi Li, Lieping Ye. 2008. Numerical simulation for the progressive collapse of concrete building due to earthquake. In The 14th World Conference on Earthquake Engineering, 12-17. Beijing.

\section{Tables}

Table 1

PGA value for the nearest fault line

\begin{tabular}{|c|c|c|c|c|c|}
\hline \multirow[t]{2}{*}{ Fault line } & \multirow{2}{*}{$\begin{array}{l}\text { PGA at } \\
\text { source } \\
\text { (g) }\end{array}$} & \multirow[t]{2}{*}{ Radius(km) } & \multicolumn{3}{|c|}{$\begin{array}{l}\text { PGA values for different maximum } \\
\text { magnitudes }(\mathrm{g})\end{array}$} \\
\hline & & & )$^{6.9(\text { Zone III }}$ & $\begin{array}{l}7.9 \text { (Zone } \\
\text { IV) }\end{array}$ & 8.9 (Zone V) \\
\hline $\begin{array}{l}\text { Chengam- } \\
\text { Alangayam }\end{array}$ & 0.78 & 45 & 0.229414357 & 0.477034965 & 0.867009374 \\
\hline $\begin{array}{l}\text { Gudiyattam } \\
\text { lineament }\end{array}$ & & & & & \\
\hline
\end{tabular}

Table 2

Building attributes

\begin{tabular}{|l|}
\hline Building type - RC frame \\
\hline Soil type - Type I ( Hard soil ) \\
\hline Ground coverage $-1431.936 \mathrm{~m}^{2}$ \\
\hline Foundation type - Shallow \\
\hline Staircase - connected \\
\hline Thickness of infill wall (Exterior) $=0.23 \mathrm{~m}$ \\
\hline Thickness of infill wall (Interior) $=0.11 \mathrm{~m}$ \\
\hline
\end{tabular}

Table 3

Score of each attribute

\begin{tabular}{|lllll|}
\hline Zone & Basic score & High rise & Vertical Irregularity & Code detailing \\
\hline III & 3 & +0.5 & -2 & +1.2 \\
\hline IV & 2.5 & +0.6 & -1.5 & +0.2 \\
\hline V & 2.5 & +0.6 & -1.5 & +0.2 \\
\hline
\end{tabular}


Table 4

Final Hazard score

\begin{tabular}{|ll|}
\hline ZONE & FINAL SCORE \\
\hline III & 2.7 \\
\hline IV & 1.8 \\
\hline V & 1.8 \\
\hline
\end{tabular}

Table 5

Section properties of elements

\begin{tabular}{|lll|}
\hline Section & Properties & Concrete grade \\
\hline Beam 1 & $0.23 \mathrm{~m} \times 0.35 \mathrm{~m}$ & $\mathrm{M} 25$ \\
\hline Beam 2 & $0.23 \mathrm{~m} \times 0.23 \mathrm{~m}$ & $\mathrm{M} 25$ \\
\hline Column & $0.23 \mathrm{~m} \times 0.45 \mathrm{~m}$ & $\mathrm{M} 30$ \\
\hline Slab & $0.13 \mathrm{~m}$ & $\mathrm{M} 25$ \\
\hline
\end{tabular}

Table 6

Maximum displacements in each case

\begin{tabular}{|c|c|c|c|c|}
\hline $\begin{array}{l}\text { Different cases for } \\
\text { comparison of the structure } \\
\text { performance }\end{array}$ & $\begin{array}{l}\text { Max drift } \\
\text { in X- } \\
\text { direction } \\
\text { (in } \mathrm{mm} \text { ) }\end{array}$ & $\begin{array}{l}\text { Max drift } \\
\text { in Y- } \\
\text { direction } \\
\text { (in } \mathrm{mm} \text { ) }\end{array}$ & $\begin{array}{l}\text { \% decrease in } \\
\text { displacement in X- } \\
\text { direction }\end{array}$ & $\begin{array}{l}\text { \% decrease in } \\
\text { displacement in Y- } \\
\text { direction }\end{array}$ \\
\hline With soft storey & 128.116 & 169.446 & - & - \\
\hline $\begin{array}{l}\text { With shear wall in ground } \\
\text { floor } \\
\text { (Fig. 5a) }\end{array}$ & 111.259 & 131.547 & $13.16 \%$ & $22.36 \%$ \\
\hline $\begin{array}{l}\text { With shear wall in staircase } \\
\text { wall } \\
\text { (Fig. } 5 b)\end{array}$ & 45.896 & 150.089 & $64.18 \%$ & $11.42 \%$ \\
\hline $\begin{array}{l}\text { With shear wall in both } \\
\text { ground floor and staircase } \\
\text { wall } \\
\text { (Fig. 5c) }\end{array}$ & 42.833 & 123.161 & $66.56 \%$ & $27.31 \%$ \\
\hline
\end{tabular}

Figures 


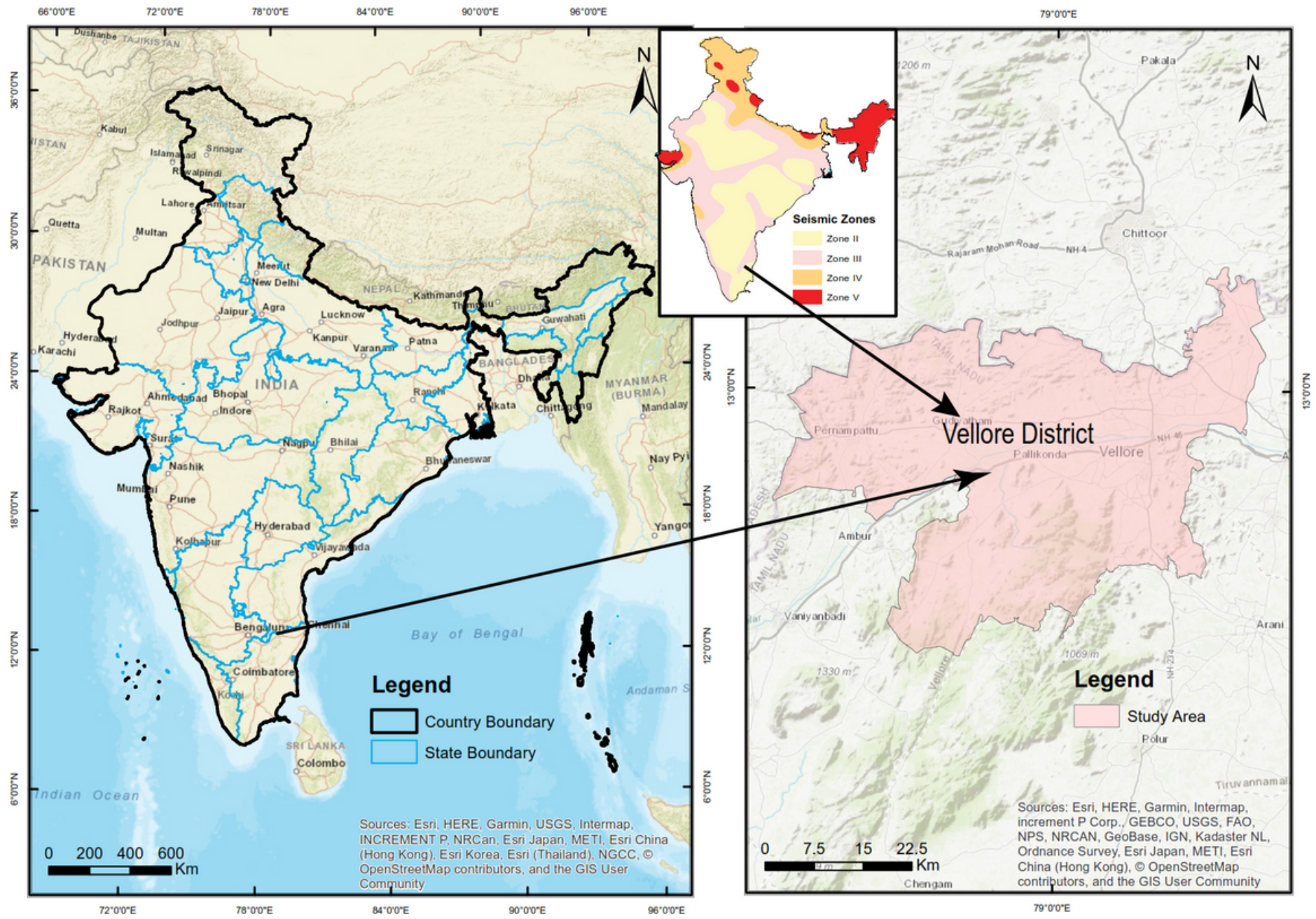

Figure 1

Figure 1 


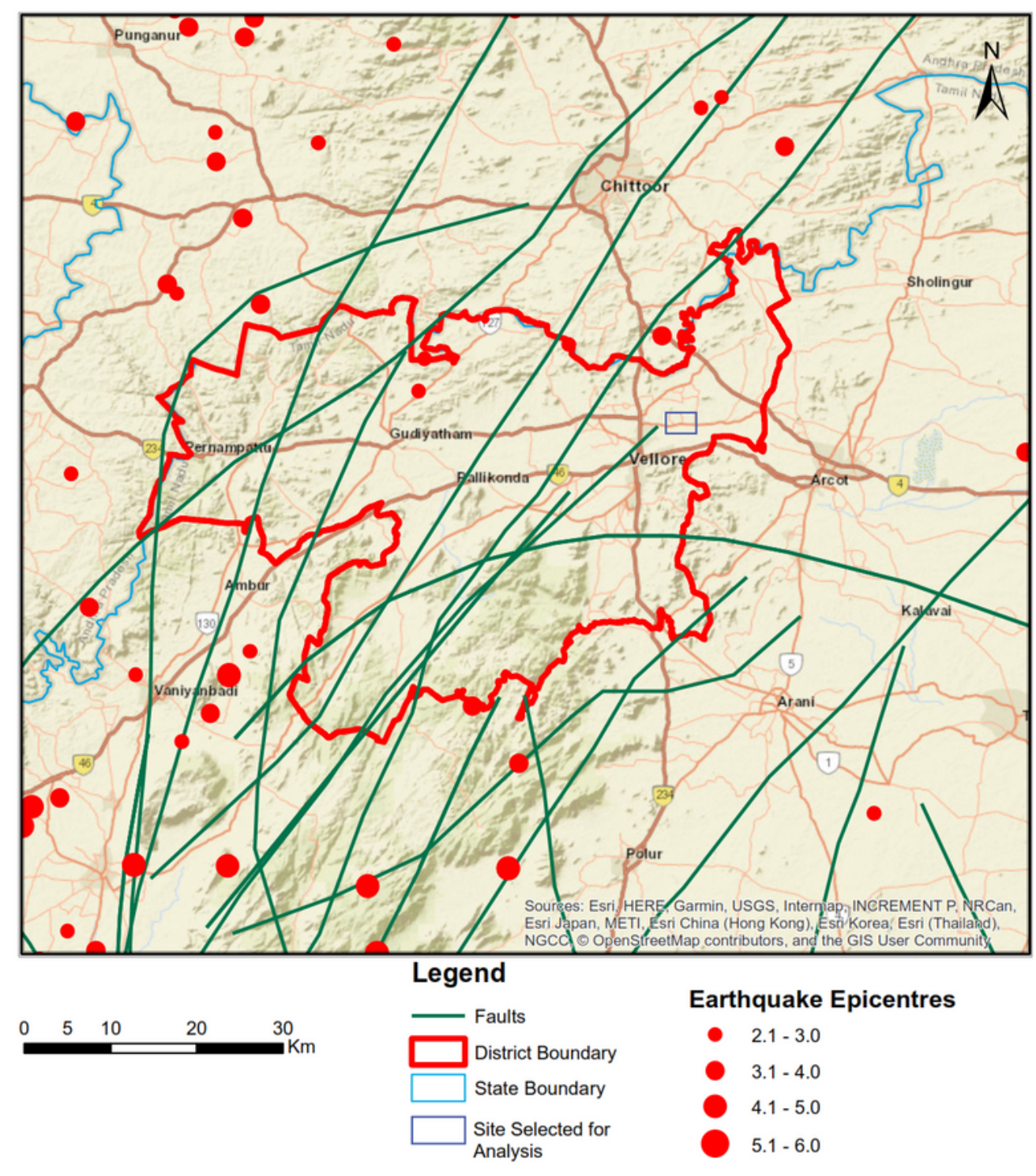

Figure 2

Figure 2 


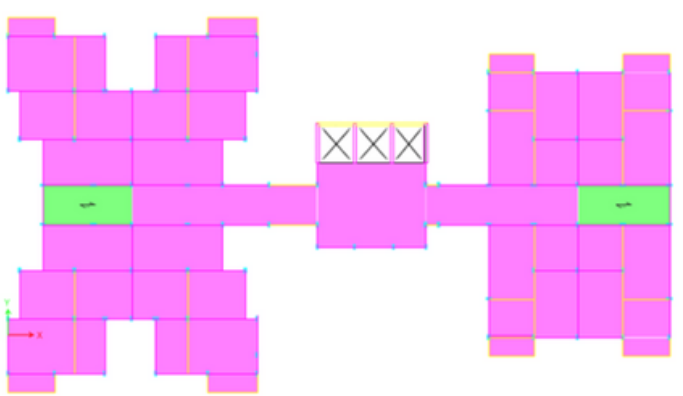

(a)

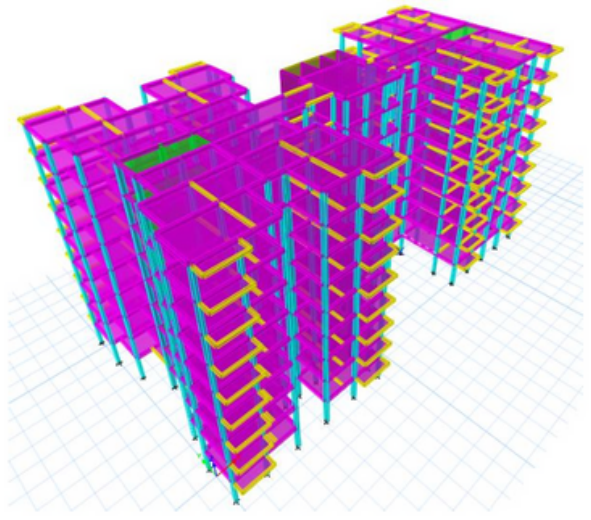

(b)

Figure 3

Figure 3

Page 12/14 


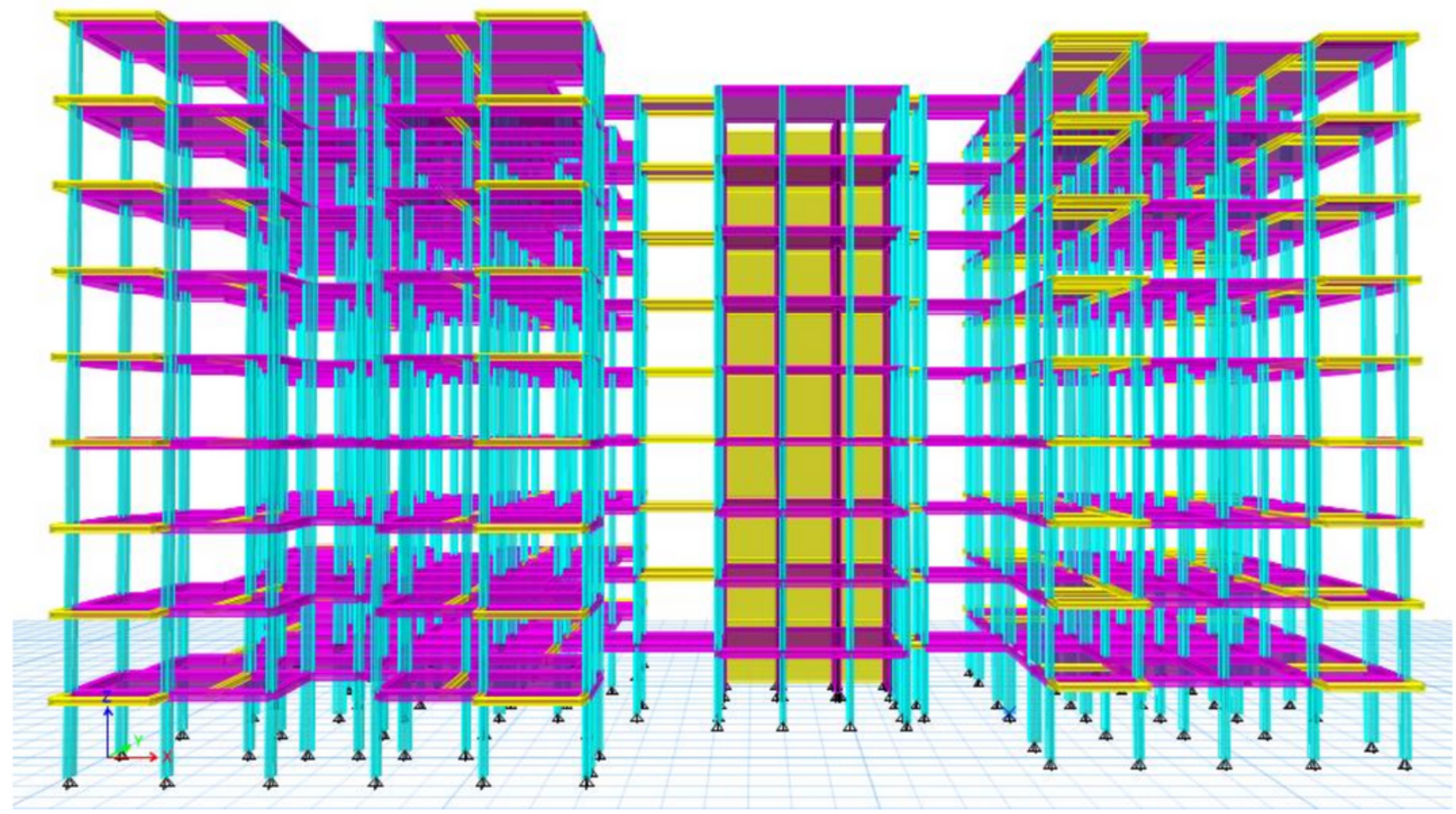

Figure 4

Figure 4 


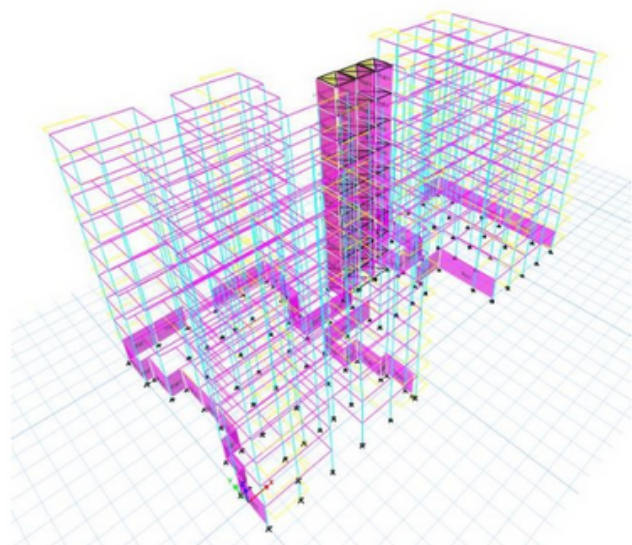

(a)

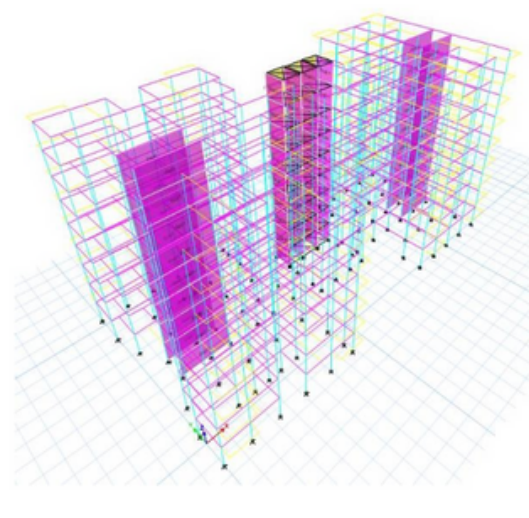

(b)

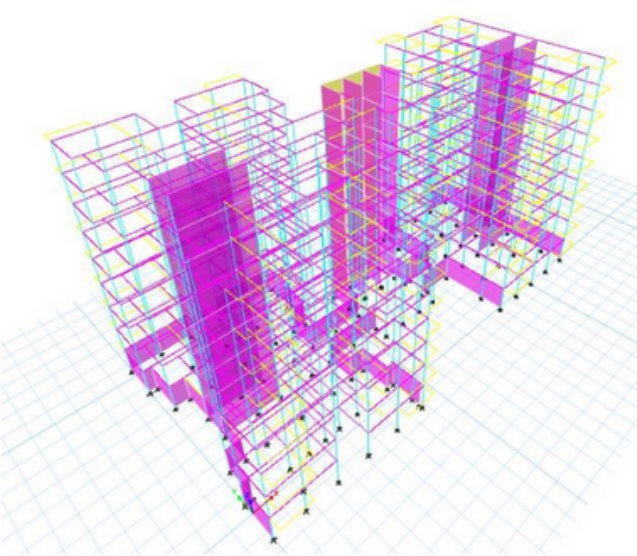

(c)

\section{Figure 5}

Figure 5 